Jiménez Hurtado, C., \& Martínez Martínez, S. (2018). Concept Selection and Translation Strategy: Subtitling for the Deaf and Hardof-Hearing. Linguistica Antverpiensia, New Series: Themes in Translation Studies, 14, 114-139.

\title{
Concept selection and translation strategy: Subtitling for the Deaf and hard-of-hearing based on corpus analysis
}

\section{Catalina Jiménez Hurtado}

University of Granada, Spain

cjimenez@ugr.es

\author{
Silvia Martínez Martínez \\ University of Granada, Spain \\ smmartinez@ugr.es
}

In the past 20 years, corpus analysis has been applied to different translation modalities. This study used an annotated multimodal corpus of 52 international films of different genres, which had been dubbed in Spanish and subtitled for Spanish Deaf and Hard-ofHearing (DHH) viewers, according to the AENOR, UNE 153010 (2012) standard. The corpus was annotated at two levels. At the first level, we annotated the information that professional subtitlers selected from the audio mode of the source text to translate into subtitles. At the second level, captured information regarding the translation strategies was used. This allowed us to analyse the translation process and reflect the translation preferences of professional subtitlers. Our first objective was to show how corpus analysis can be applied to the study of multimodal texts. The second objective was to provide valuable insights into the understanding, description and specification of the conceptual and epistemological nature of subtitling for the $\mathrm{DHH}$.

\section{Introduction}

Translation Studies has been influenced by academic and cultural trends that have determined research objectives. Apart from work on the cognitive foundations of the translation process (Muñoz Martín, 2017; Risku, 2014; Schwieter \& Ferreira, 2017), there is also the urgent need to find analytical parameters that will help to resolve issues stemming from the social, cultural (Ranzato \& Zanotti, 2018) and technological dynamics of the visual turn (Bateman, Delin, \& Henschel, 2004; Chica Núñez, 2016; Díaz Cintas \& Neves, 2015).

Despite the fact that translators have been working with audiovisual texts for decades, scholars in Translation Studies have only recently discovered concepts such as multimodality, multimediality and intersemioticity from a scientific perspective (Elleström, 2010). As a result, they have recently begun to analyse the strategies used in these cognitive and communicative phenomena to create meaning in the target text (TT) (Jewitt, 2009; Kaindl, 2013; Ketola, 2016). The Digital Age has led to a proliferation of multimodal texts that must be translated. This has generated the need for new research tools. Bateman et al. (2004) write:

One of the corollaries of the broadening in the area of concern is that we are forced to deal with systems which are manifestly meaning-making (e.g., photographs, diagrams) but for which we lack the rich battery of investigative tools that we now have for linguistic entities. (p. 65)

This is the case with audiovisual translation (AVT), which also includes accessible translation (Álvarez de Morales Mercado, 2015; Jiménez Hurtado, 2007; Jiménez 
Hurtado 2010). According to Munday (2012, p. 268), AVT is faced with the challenge of defining its epistemological and conceptual nature. Furthermore, it must overcome the distance that separates the different multidisciplinary, multimodal, multimedia and linguistic approaches to its analysis.

Our aim was to contribute to the epistemological description of multimodal translation and to demonstrate how corpus analysis could be usefully applied to both the study of multimodal texts and the complex communicative and intersemiotic process of translating sounds into words. This article therefore considers two important issues related to the meaning-making process in the translation for the Deaf and Hard-ofHearing $(\mathrm{DHH}) .{ }^{1}$ Since DHH text receivers cannot access the sounds transmitted in the source text (ST), translators must create a TT that compensates for this deficit and focuses on the translation of acoustic content.

This research therefore used a corpus of films to extract and analyse elements of acoustic content which were selected by the translator for inclusion in the TT because of their relevance and frequency. This provided us with valuable information about these elements that facilitate access to the acoustic information in film texts.

Once the contents were selected, we analysed the linguistic and cognitive strategies used to translate the sounds into words. We were also interested in studying the recurrence and coherence of this multifaceted translation activity, which inevitably entails simplifying the text to some degree. This process is extraordinarily complex because it entails translating a semiotic code (sound) that is not accessible to the DHH receiver into another linguistic semiotic code (Spanish).

Translating for the DHH involves the use of translation strategies that facilitate their access to the information in the text. Our methodology was based on the analysis of multimodal corpus data.

\section{Multimodal corpus analysis}

\subsection{Structure and function of the corpus study}

Thanks to the burgeoning use of corpora (Baños Piñero \& Díaz Cintas, 2015), research in Translation Studies, as well as in Linguistics, has acquired a more empirical dimension. An optimal way of providing a solid foundation for research into how multimodal texts create meaning is to compile a large collection of texts that are representative of a certain text genre. The analysis of the data extracted leads to results that can provide important insights into the research question. It goes without saying that the quality of the results inevitably depends on the size and design of the corpus, and finally on its capacity to be linguistically annotated or tagged (Jiménez Hurtado, 2010, p. 57; Laviosa, 2015).

According to Allwood (2008), a multimodal corpus can be described as follows:

[...] a multimodal corpus is a digitized collection of language and communicationrelated material drawing on more than one sensory modality. In a more narrow sense, we might require that the audiovisual material should be accompanied by transcriptions and annotations or codings based on the material. (p. 208)

Allwood (2008) affirms that there are three types of annotation: (i) texts that describe images; (ii) audiovisual recordings with annotations, and (iii) audiovisual recordings with transcriptions. All three types should be defined in terms of their spatio-temporal synchronization, which can also be a source of difficulties.

Abuczki and Ghazaleh (2013) highlight the following problems: 
Multimodal corpus (henceforce: MM corpus) research faces two major problems: (1) the time-consuming nature of annotation process, therefore, relatively small sizes of annotated MM corpora are available; (2) the lack of existing annotation standards (tools, formats and schemes), especially for coding nonverbal behavior. (p. 87)

The objectives of most annotated multimodal corpora (e.g., AMI, SmartKom, HuComTech) are related to the study of human interaction. More specifically, they focus on face-to-face interaction. These tagging systems are not only semantic in nature but can also annotate content such as emotions, types of communicative interaction in groups and even gestures (Abuczki \& Ghazaleh, 2013). All of these are task-oriented corpora, since the data were annotated with a specific purpose in mind.

Despite the fact that they are not typically multimodal corpora, multimodal parallel corpora can be used to create terminological knowledge bases and generate translation dictionaries enhanced with corpus examples and semantic networks of the search term (e.g., EcoLexicon, ecolexicon.ugr.es).

\subsection{Multimodal corpus analysis in multimodal translation}

Díaz Cintas $(2005$, p. 63) underlines the interest of applying corpus analysis to AVT. Valentini (2006, p. 2) emphasizes the importance of using annotated multimodal corpus examples to obtain empirical data and adapting them to the needs of the translation process. In the same way as for other modalities, research on dubbing has generally been in the form of case studies (Taylor, 2004). Nevertheless, exceptions include Baldry and Thibault (2006) and the Forli Corpus of Screen Translation, composed of 30 annotated films in French, Italian and German for teaching dubbing translation (Heiss \& Soffritti, 2008; Valentini, 2006, 2008).

In audio-description (AD), the TIWO (Television in Words) corpus consists of 91 audio-described film scripts annotated in British English (Salway, 2007, p. 155). There is also the TRACCE (Traducción y Accesibilidad) corpus composed of more than 300 audio-described films. A multimodal tagging tool (Taggetti) was also created to describe the translation of images into words and therefore study its didactic and professional applications (Jiménez Hurtado, 2010; Jiménez Hurtado \& Soler Gallego, 2015; Jiménez Hurtado, Seibel, \& Soler Gallego, 2012).

Interlingual subtitling has been studied with a corpus, though in most cases the corpus was not annotated (Mattsson, 2009; Tiedemann, 2007; Tirkkonen-Condit \& Mäkisalo, 2007). The Veiga English-Galician corpus (Sotelo Dios \& Gómez Guinovart, 2012) is composed of 40 audiovisual texts, which are partially annotated. To study the strategy of explicitation, Feitosa (2009) used a corpus to compare fansubs with the original subtitles of 10 Brazilian films. Furthermore, the SUMAT (2012) project created an annotated corpus with subtitling in nine European languages, combined in 14 language pairs. This corpus was applied to the automatic translation of subtitles; the aim was to compare the final translations and provide guidelines for improving the translations of each language pair. Martí Ferriol $(2010,2013)$ analysed a corpus of five American films, made by independent film producers and released in Spain from January 2001 to June 2004. In 2010, he performed a qualitative analysis of the comparison of the dubbed and subtitled versions of these films. Four years later, he published a more academic explanation of the theoretical foundations of his previous 2010 study, which focused on the translation method and on the three parameters used to characterize it: (i) the restrictions inherent in AVT; (ii) translation norms, and (iii) translation techniques.

Subtitling for the Deaf and Hard-of-Hearing (SDHH) is similar to that for other modalities of multimedia translation in that most of the corpora used in previous research were quite small, based on a relatively small number of films. Furthermore, the analysis 
was often restricted to one film and its subtitles. In line with this, relevant research has focused on the observation of children's films with untagged SDHH (de Moraes Abrahão, 2014; Kalantzi, 2008; Lorenzo García \& Pereira Rodríguez, 2011). Zárate (2014) compiled an untagged corpus of episodes from two children's programmes on five national television channels in the United Kingdom with a view to analysing how deaf children accessed the knowledge in them.

On the other hand, Kalantzi (2008) used an unannotated corpus of 360 SDHH from two documentaries and BBC news broadcasts in which the author focuses on segmentation and deletion. There are also a number of Master's theses on this topic, which examine a certain aspect of SDHH. One example is that of de Moraes Abrahão (2014), who analysed the verbs used in subtitles for the deaf in three films.

More recently, Martínez Martínez (2015) studied the translation strategies used in SDHH. For this purpose, she compiled an annotated multimodal corpus of 30 films, which was used in this research study. Finally, Pessoa do Nascimiento (2017) analysed a corpus of 15 annotated Brazilian Portuguese films to study the translation of sound effects and create a set of professional guidelines.

\section{TRACCE-SpS corpus}

\subsection{Corpus compilation combined with a tagging application}

TRACCE-SpS is a corpus of accessible multimedia texts for the DHH. It was compiled with a view to describing the cognitive and semantic processing involved in translating sounds into words. It is composed of $52^{2}$ films dubbed in Spanish, which have been subtitled for the DHH. The films are divided into three groups. The first group consists of films in the collection Cine para todos (2012); the second is composed of films subtitled by the company Navarra de cine; the third consists of films by the newspaper El Pais; and the fourth comprises films marketed by other companies (i.e., $A$ Contracorriente Films S.L.).

When the corpus was compiled, it was then digitalized with the Camtasia Studio computer application, which captures and edits video files. The subtitles were obtained with SubRip, a program that extracts subtitles and their timings from videos. However, because of problems experienced with the program, most of the subtitles were finally transcribed manually.

The next phase involved finding a tagging program. Tagging or annotating is far from a simple process because of the time involved and because the coders must be coherent and all of them must apply the tags in the same way. To simplify the process, we tested the software programs Atlas.ti, Nvivo, ELAN-Linguistic Annotator and $M A X Q D A$. Of these, MAXQDA was found to be the most suitable because of its flexibility, data-analysis and -exportation options, and their usability. It is a program designed for use in computer-assisted qualitative, quantitative, and mixed methods data, text and multimedia analysis. It is able systematically to evaluate and interpret texts. The program is simple to configure and enables users to work collaboratively, share coded documents, combine projects, edit texts with colours, symbols and typography, and analyse whether codes coincide in a segment. In addition, it can align the tags manually with their corresponding video segments.

Another interesting characteristic of this software is that its interface is simple to configure. Figure 1 shows the configuration and design that we considered optimal for our purposes. As can be observed, the tagging tree is at the far left. The subtitles to be tagged appear in the centre of the screen. On the right, there is a multimedia player with the video and soundtrack. The window at the bottom right of the screen shows a list of frequent tags, which facilitates the tagging process. 


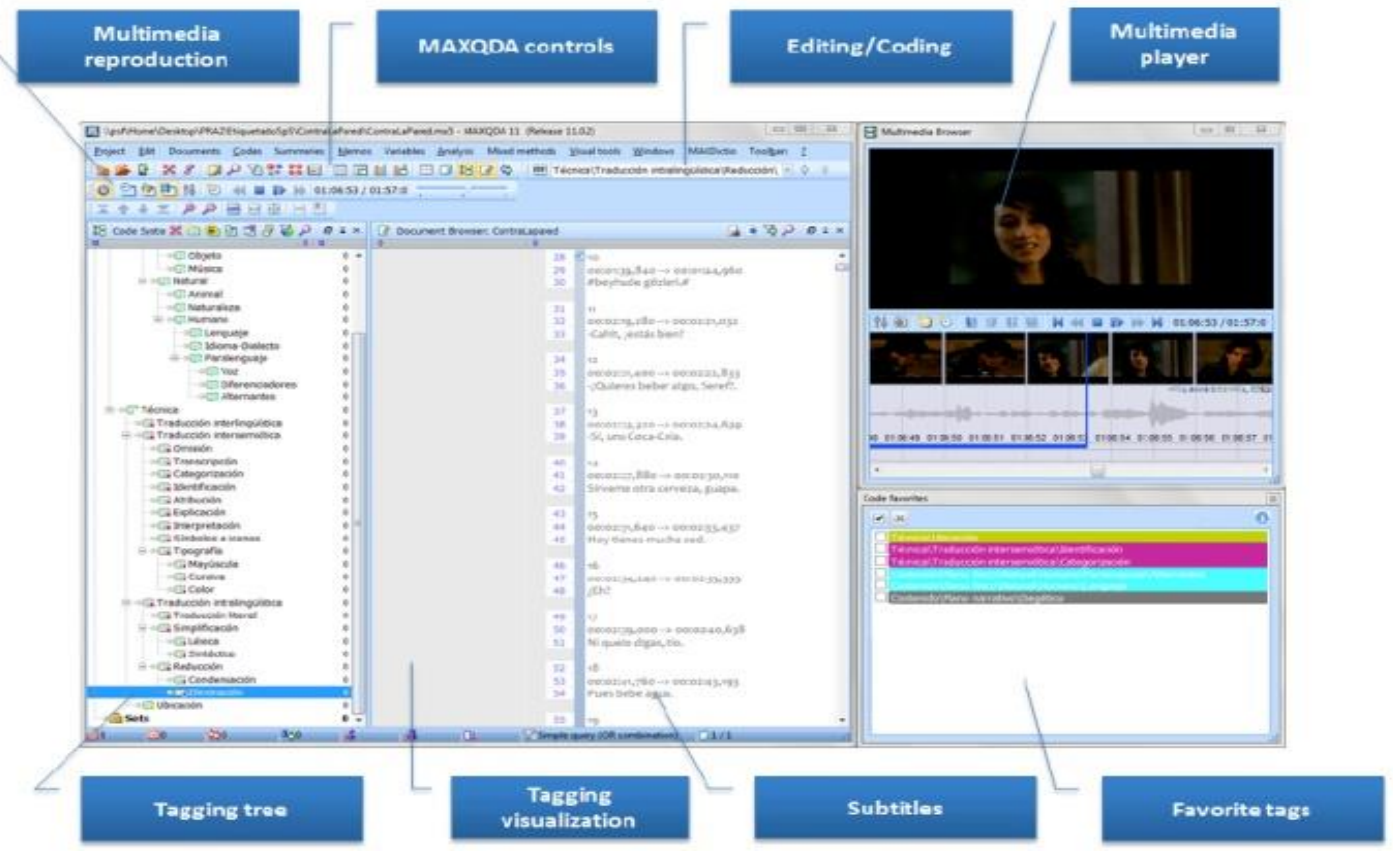

Figure 1: MAXQDA Interface

Another reason for selecting this tool was that it allowed us to include an unlimited number of tags and nest them in each other, modify them or eliminate them. It is also possible to add comments to a tag and even to create a document for notes. As shown in Figure 2, these tags are located to the left of the subtitling window. This makes it possible to view and access the tags that correspond to each subtitling unit.

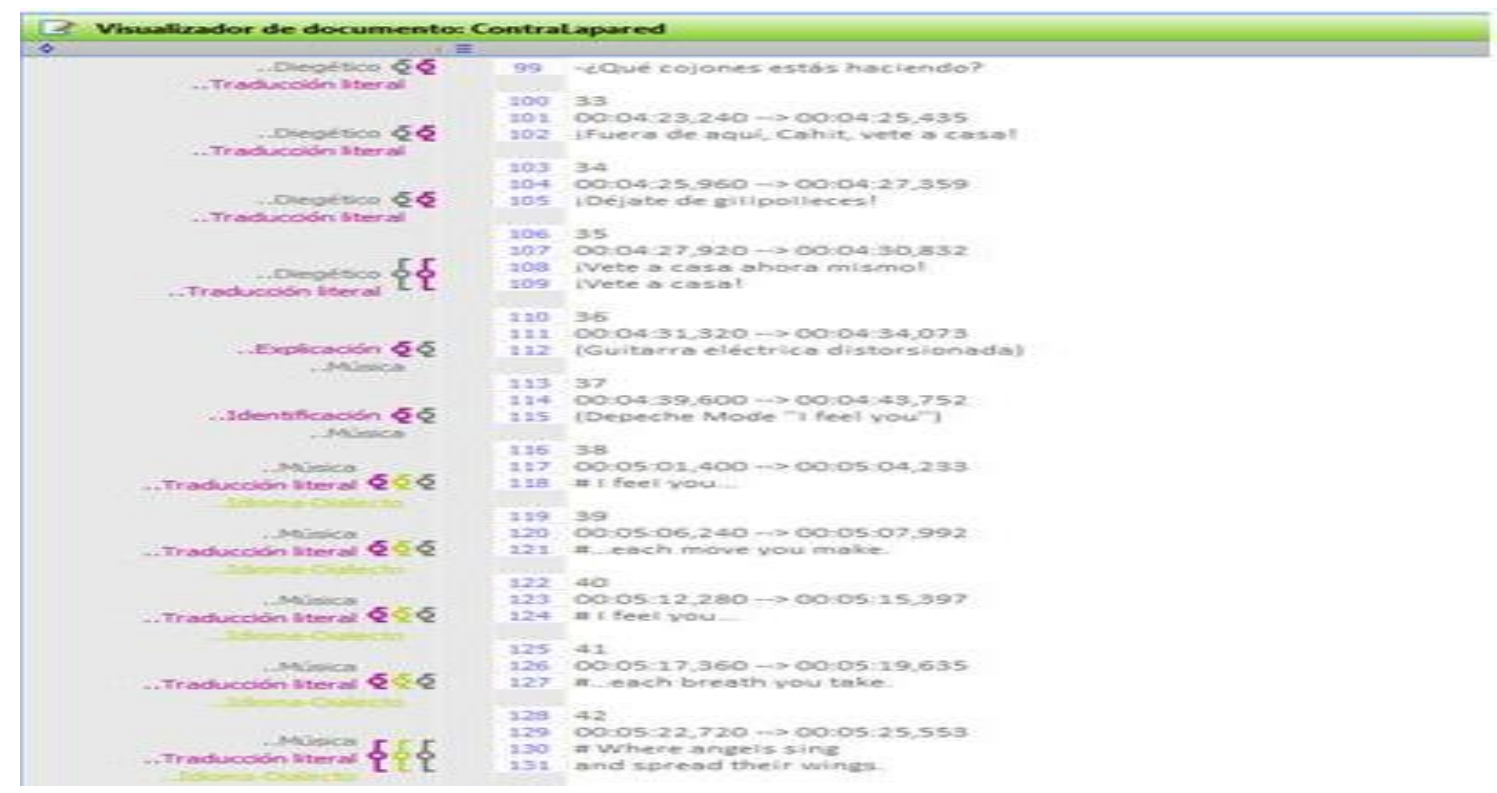

Figure 2: Subtitling units and their corresponding tags 
An indispensable part of the analysis was the agreement between coders, since this guarantees consistent tags or codes throughout the process. When there are discrepancies, there is the evident need to reflect on the use of each problematic tag (Nancy \& Pustejovsky, 2017; Peña y Lillo, 2012).

The final stage in the preparation of the corpus was to create an annotation system, specifically conceived to analyse the selection of the acoustic contents in the ST and the strategies implemented to translate them.

The tag selection process was very complex. Before specifying a definitive tag hierarchy, an initial sample of proposed tags was tested on different film extracts. Two films were then analysed by two groups of five researchers each. The level of agreement was then verified between the individual researchers in each group as well as between the two groups as a whole. For this purpose, we extracted the results for each film and analysed the main causes of discrepancy between taggers. This process revealed a series of errors. For example, certain of the researchers assigned tags to each of the lines in the subtitle whereas others tagged the subtitle as a whole.

Yet another problem was the partial overlapping of certain tags, such as Categorization, Attribution and Explanation. These tags are not included in any previous list of translation strategies and techniques. For this reason, it was necessary to establish clear boundaries between them. After this was accomplished, a standard protocol of action was created in order to unify the tagging process and eliminate divergences in the way tags were assigned.

\subsection{Two-level tagging of film sound}

Our tagging system has two levels; they correspond to the two stages in the process of translation of sounds into words. Level 1 tags identify and classify the verbal and nonverbal acoustic elements of the ST (audio content), which are relevant to the creation of the multimodal meaning in the film. Level 2 tags specify the strategies used in the translation of film sound (dialogues, music and sound effects) into words (translation strategies). As will be seen, these traditional tags have been expanded because of the characteristics of the translation process.

\subsubsection{Level 1 tags: audio content}

UNE standard 153010 (2012), Spanish norm for SDHH, published by AENOR, makes no distinction between different types of sound. Nor does it specify how each should be translated. It is evidently not conceived as a tool for analysing the translation of SDHH, and thus does not provide any guidelines for this process. It only generally focuses on the technical and visual aspects of these subtitles. However, it does recommend that sound effects should be accurately reflected so that viewers can better follow what is happening in the film (UNE 153010, 2012, p. 13). In line with this, it explicitly states that when it is not evident that a sound event has occurred, such event should be subtitled.

Accordingly, the first level of the tagging system was based on both acoustics research (Kostantinidou, 2012; Llinares, 2012; Rumsey \& McCormick, 2014) and film sound studies (Bordwell \& Thompson, 2010; Chion, 2008; Flückiger, 2001; Kellner, 2011), which were divided into two subsets. The first subset corresponds to the film narratology that is related to the decisions of the director of the film and which refers to the intentional use of sound in the film-editing process, namely, diegetic sound and extradiegetic sound. The second subset of tags refers to the physical nature of sound and is based on the general classification of sound in the world.

Regarding the first subset, various authors have classified film sound based on the emission source and origin in the narrative. Gorbman's (1987) classification is based on 
the conventional dichotomy between diegetic and extra-diegetic sounds. A third, metadiegetic level is also included that refers to the imagined and hallucinated sounds perceived by a character. Bordwell and Thompson (2010) make the distinction between diegetic and non-diegetic sounds. Chion (2008) subclassifies these two phenomena as sounds that are on-screen, off-screen or outside of the visual field. In contrast, Flückiger (2001, p. 3) proposes a more open-ended approach that even includes all of the sounds that do not have a clear source in the image. She refers to these as unidentified sound objects (USO). In consonance with the majority of these authors, our classification distinguishes only between diegetic and extra-diegetic sounds.

As previously mentioned, the second subset refers to the physical nature of sound and is based on the general classification of sound from a physical perception of the world. This level of analysis evidently does not depend on the production process of a film text but exclusively refers to sound as a physical phenomenon. As such, sounds can be either artificial or natural (Schafer, 2003).

More specifically, natural sounds are those emitted in nature and their source can be any living organism or any non-biological natural force, such as rain or thunder. This sound category therefore includes tags such as these:

- $\quad$ nature sounds

- $\quad$ animal sounds

- bodily sounds emitted without the use of an object or an artefact.

Each level in turn has different sublevels. The classifications are hierarchical, and the most specific tags are always selected since they include the previous ones. Whereas Nature and animal are final tags, Human includes tags such as Bodily action, Language, Language-dialect and Paralanguage, which is not a final tag either, and includes the tags Voice and Alternations (see Figure 3).

The tag Bodily action refers to bodily actions performed without the intervention of an object and which produce a characteristic sound, such as applause and footsteps resulting from the actions of applauding or walking, respectively (Poyatos, 1994 II, pp. 185-186). Paralanguage is a vocal communicative activity that refers to the nonverbal qualities of the voice and its modifiers (Poyatos, 1994 II, pp. 28-29). These modifiers in turn are determined by physiological and biological factors and can also be affected by emotional and psychological factors. Their importance stems from sociocultural modifiers of the voice, especially since these comprise an extraordinarily complex set of effects that are perceived and judged differently. For example, a murmur can signal intimacy, though in other cases murmuring can make other people uncomfortable (Poyatos, 1994 II, pp. 49-50).

Alternations are also known as emotional and physiological sounds, and are usually accompanied by other linguistic, kinesthetic or paralinguistic signs. Accordingly, this category can be modified by certain primary voice characteristics or its classifiers: tone, volume, intonation and register. 


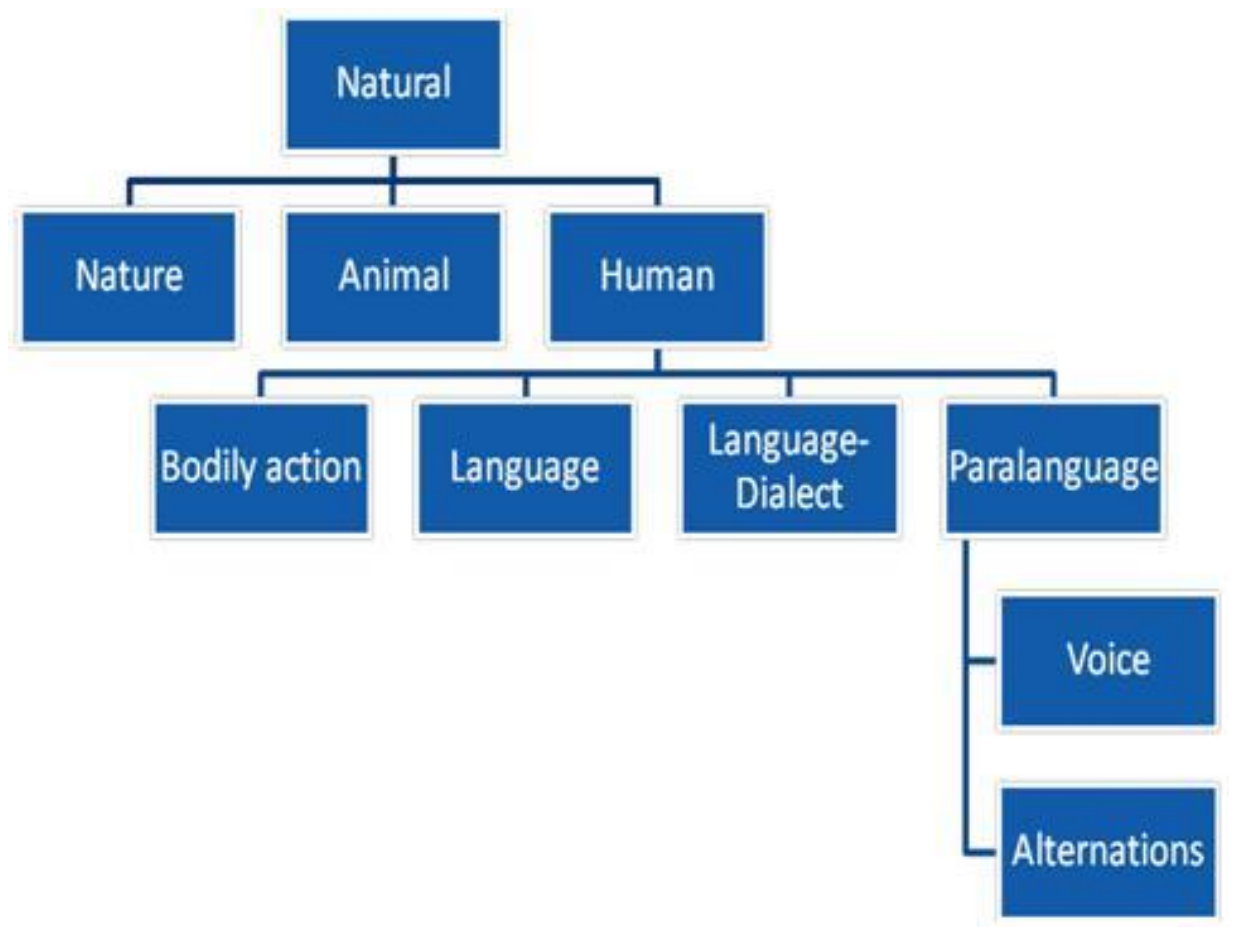

Figure 3: Hierarchy of natural sound tags

The second subset includes artificial sound tags, which are divided into sounds produced by artefacts and musical sounds. Bordwell and Thompson (2010) define artificial sound as sound that is part of a scenario and which blends into it to the extent that there is no need to locate or visualize the source (e.g., the sound of church bells ringing). According to Chion $(2008$, p. 81 ), artificial sounds can be present in a scene, but are transmitted electrically by a radio, telephone, loudspeaker, etc., and therefore escape the natural mechanical laws of sound propagation.

Although these tags are evidently in need of further study, they allowed us to elaborate on and test a methodological framework that provides results about the actions of professional subtitlers.

\subsubsection{Level 2: Translation strategies}

The classification of translation strategies used in the SDHH is based on Martí Ferriol (2013), Neves (2005) and Díaz Cintas and Remael (2007). Its purpose was to identify and categorize the strategies used to translate sounds.

This level is divided into three basic categories that coincide with Jakobson's (1959) well-known classification: interlingual, intralingual and intersemiotic translation.

Despite the fact that interlingual translation (translation between languages) is the least frequent modality in SDHH, it was included in the tagging system in order to ascertain its relevance statistically. Furthermore, AENOR, UNE standard 153010 (2012) includes precise recommendations for this type of translation. As shown in Figure 4, the set of strategies activated in intersemiotic translation can be divided into the following seven categories. 
Omission is one of the strategies proposed by Martí Ferriol (2013, p. 120), who defines it as the total suppression in the TT of any element in the ST. In the bottom-up analyses that were performed prior to tagging, it was found that during the translation process sounds that were relevant to the plot were eliminated and not included in the subtitles. The same occurred with the transcription of certain types of interjection and onomatopoeia, which is often present in children's films, although to our knowledge it does not appear in any classification of conventional subtitles or SDHH.

The most innovative group was composed of the following final tags: Categorization, Attribution and Explanation. The results of our research showed that subtitlers frequently used these strategies to translate sounds that do not generally have a linguistic designation. For example, when a film shows an open tap with running water filling a basin, the sound of the water coming out of the tap and splashing onto the porcelain surface cannot be explicitly translated because of space constraints. Instead, it is necessary to find ways to categorize it. If the subtitler decides that basic categorization (tap, water) is not sufficient, they must add information that makes this information more specific (tap water, open tap). If even further details are required, then it is necessary to add an explanation with more contextual information such as the location (kitchen tap) or intensity of the sound-producing action (wide-open tap).

These strategies are similar to the basic parameters that govern ontology-building (Gruber, 1995, 2001). As is well known, human beings have access to world knowledge through their perception. They use their five senses to perceive the entities in their immediate environment and, based on the characteristics perceived, they then classify them as objects, events, qualities or relationships (Evans \& Green, 2006). Consequently, the tag Categorization refers to the basic cognitive activity of intersemiotic translation and consists of specifying any of the following:

- $\quad$ conceptual category of the sound (rain, thunder);

- $\quad$ agent producing the sound (shopkeeper, bird, Julia);

- $\quad$ action producing the sound (crying, playing the piano, knocking on the door);

- $\quad$ result of the action (laughter, shouting, crying, music);

- $\quad$ instrument used to produce the sound (door, car).

Attribution involves assigning qualities to a sound. Attribution is subsequent to Categorization and can either be explicit (harmonious music) or implicit (shouting [loud talking], stammering [nervous talking]). Even though Categorization and Attribution are similar, it is necessary to differentiate them because it is possible for one to occur without the other.

Explanation in a subtitle is a description of information regarding the production of a sound that is not related to a specific property but rather to its relation to other entities (e.g., playing a very low note). Explanation thus follows Categorization and Attribution, but may include them either explicitly (e.g., the conversation overlaps with the previous images) or implicitly (e.g., background shouting continues), based on the images in the film.

The last set of tags refers to symbols, icons and typography. This group is based on AENOR, UNE 153010 (2012), on SDHH, regarding what is standard and non-standard.

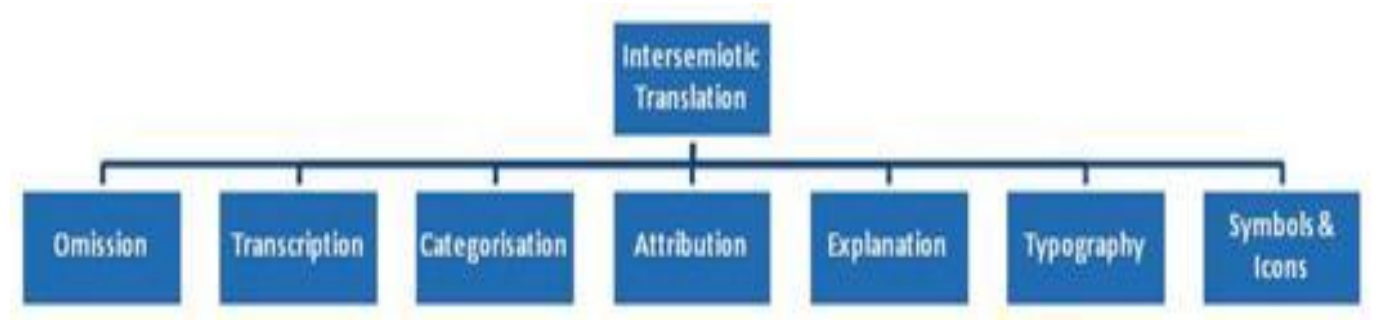


Figure 4: Translation strategies for intersemiotic translation

Finally, intralingual translation was divided into the following subtypes:

- $\quad$ Literal translation

- $\quad$ Simplification

- Lexical simplification

- Syntactic simplification

- $\quad$ Reduction

○ Condensation

○ Elimination.

According to various authors, simplification occurs either because a viewer's reading capacity lags behind the perception of spoken dialogue (Neves \& Lorenzo García, 2007) or because a DHH person has limited access to the Spanish language (Cambra i Vergés, 2006; Cambra, Silvestre \& Leal, 2015, p. 254). In addition, other authors have made proposals regarding the elements that can be eliminated (Díaz Cintas, 2003, 2010; Ivarsson \& Carroll, 1998; Karamitroglou, 1998). Nevertheless, these strategies need to be further studied because at the moment there is a certain conceptual overlap and certain lack of certainty (Cabo Villarpriego, 2008, p. 8; Díaz Cintas, 2003; Martí Ferriol, 2013, p. 120).

Our research differentiates Simplification from Reduction, depending on the context. More specifically, the use of Reduction stems from temporal and/or spatial restrictions in the subtitling derived from the medium in which it happens. In contrast, the objective of Simplification is to make the message more understandable for the receiver by using simpler vocabulary or syntax.

\section{Results and discussion: Data selection and comparison}

Corpus composition and tagging affords researchers the possibility of extracting information regarding the frequency of the tags for each film as well as for different groups of films. For instance, it is possible to compare subtitles created by different companies or even to analyse the different film genres in the corpus.

Section 4.1 lists the frequencies of the different tags used in one film and also in the entire corpus. All of the frequency data are shown in Table 1 along with their percentage of use at each level. In section 4.2 data are given for each subtitling company. Finally, section 4.3 cross-matches tags of different levels to show the wide-ranging possibilities of this method of analysing SDHH. The results obtained provide valuable insights into the translation tendencies in SDHH in Spain and by different subtitling companies. These three subsections give the percentage of tag use along with an explanation of the multiple possibilities of such an analysis.

\subsection{Results for general frequency}

The initial data of the TRACCE-SpS corpus are given in tables showing the frequency of tags in each film. Table 1 shows the tag frequencies for the film Amor (2012). 


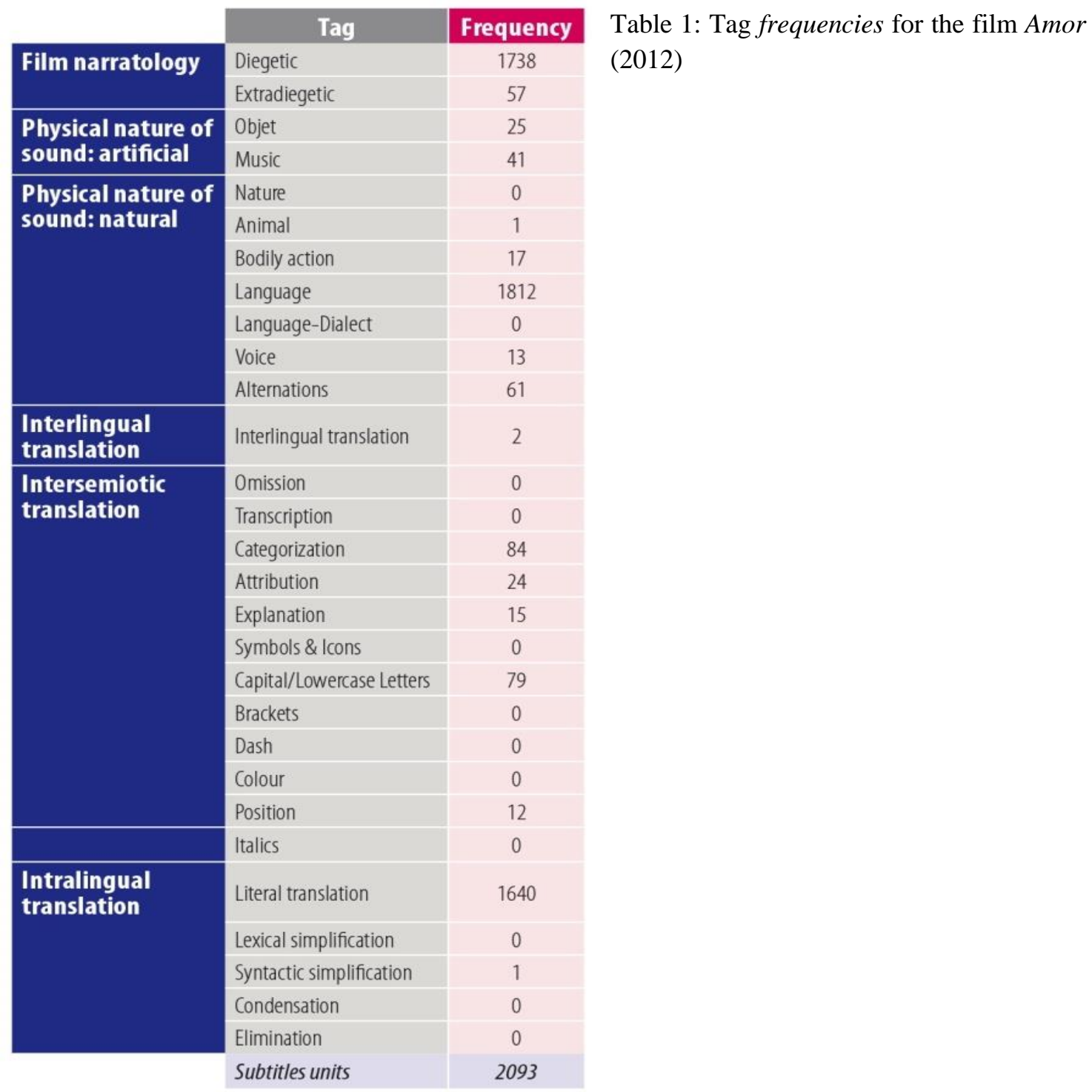

The middle column in Table 1 lists the name of the final tag. The left-hand column shows the hierarchy level to which each tag belongs. The right-hand column lists the number of times that each tag was used in the film. The bottom row gives the total number of subtitled units, which can have various nested tags. Once the frequency was obtained for each tag, its percentage of use was calculated (see Figure 5). 


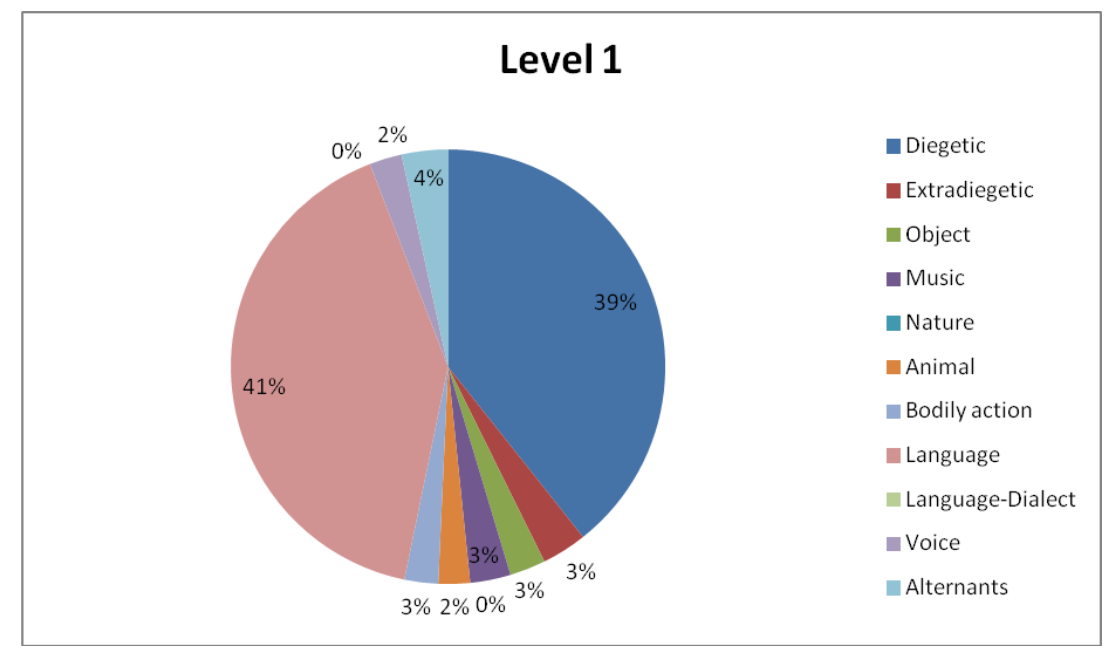

Figure 5: Use percentages of Level 1 tags.

More specifically, the data for Amor show that the most frequently used tags were Language (41\%, physical sound) and Diegetic sound (39\%, narrative level). These results are hardly surprising, because dialogues are the most frequent sound components in films. The remainder of the components had percentages ranging from $0 \%$ to $4 \%$. This is striking, given the fact that this film is about Music, a tag with a percentage of only $3 \%$.

Interestingly, these data indicate that nature sounds $(0 \%)$ were not tagged, which is in consonance with the fact that Amor (2012) was filmed almost entirely indoors. Still another example is the frequency of the Alternants tag, which refers to the way in which people emit sounds. Instances of Alternants include stammering, stuttering and hissing.

As shown in Figure 5, the Object tag is comparatively infrequent (3\%). This is justified by the fact that the dialogues drown out most of the other sounds. Paradoxically, the silence in this film is deafening and indicates the moments when any of the main characters escape or disconnect from the real world.

These examples are evidence that the distribution and hierarchy of our tags could be improved. One possibility would be to establish three levels of audio tags that correspond to the levels of conceptual objects in the film soundtrack: (i) dialogues; (ii) music, and (iii) sound effects. This would lead to the development of a tagging system for each one. A tag could also be included for silence or the absence of sound.

A general descriptive analysis indicates the sum of all the frequencies (see Table 2) as well as the frequency percentages (Figures 6 and 7). 
Table 2: Frequency of corpus tags

\begin{tabular}{|c|c|c|}
\hline & Tag & Frequency \\
\hline \multirow[t]{2}{*}{ Film narratology } & Diegetic & 37331 \\
\hline & Extradiegetic & 2061 \\
\hline \multirow{2}{*}{$\begin{array}{l}\text { Physical nature of } \\
\text { sound: artificial }\end{array}$} & Objet & 621 \\
\hline & Music & 883 \\
\hline \multirow{7}{*}{$\begin{array}{l}\text { Physical nature of } \\
\text { sound: natural }\end{array}$} & Nature & 52 \\
\hline & Animal & 83 \\
\hline & Bodily action & 179 \\
\hline & Language & 34671 \\
\hline & Language-Dialect & 581 \\
\hline & Voice & 1038 \\
\hline & Alternations & 1091 \\
\hline $\begin{array}{l}\text { Interlingual } \\
\text { translation }\end{array}$ & Interlingual translation & 1357 \\
\hline \multirow{12}{*}{$\begin{array}{l}\text { Intersemiotic } \\
\text { translation }\end{array}$} & Omission & 154 \\
\hline & Transcription & 319 \\
\hline & Categorization & 2401 \\
\hline & Attribution & 963 \\
\hline & Explanation & 908 \\
\hline & Symbols \& Icons & 95 \\
\hline & Capital/Lowercase Letters & 448 \\
\hline & Brackets & 9 \\
\hline & Dash & 4 \\
\hline & Colour & 1 \\
\hline & Position & 764 \\
\hline & Italics & 417 \\
\hline \multirow[t]{6}{*}{$\begin{array}{l}\text { Intralingual } \\
\text { translation }\end{array}$} & Literal translation & 32210 \\
\hline & Lexical simplification & 51 \\
\hline & Syntactic simplification & 245 \\
\hline & Condensation & 253 \\
\hline & Elimination & 449 \\
\hline & Subtitles units & 32214 \\
\hline
\end{tabular}

As can be observed, the pattern is the same as the one used for the analysis of a single film, except for the fact that all of the tags are activated. When tags that lead to skewed statistical values are eliminated, the most frequent are Alternants and Voice. This signifies that all phenomena modifying voice are usually highlighted. They can be regarded as key factors in the understanding of verbal and kinetic stimuli, and are therefore extremely useful to the DHH film viewer.

Object and Music are the next most frequent tags. This indicates that music is a central element in the film narrative. Moreover, Object is a tag that is steadily increasing in importance. This may be due to the fact that the translator categorizes the source of the sound component. In fact, this analysis indicates that this tag should be subdivided into other elements. 

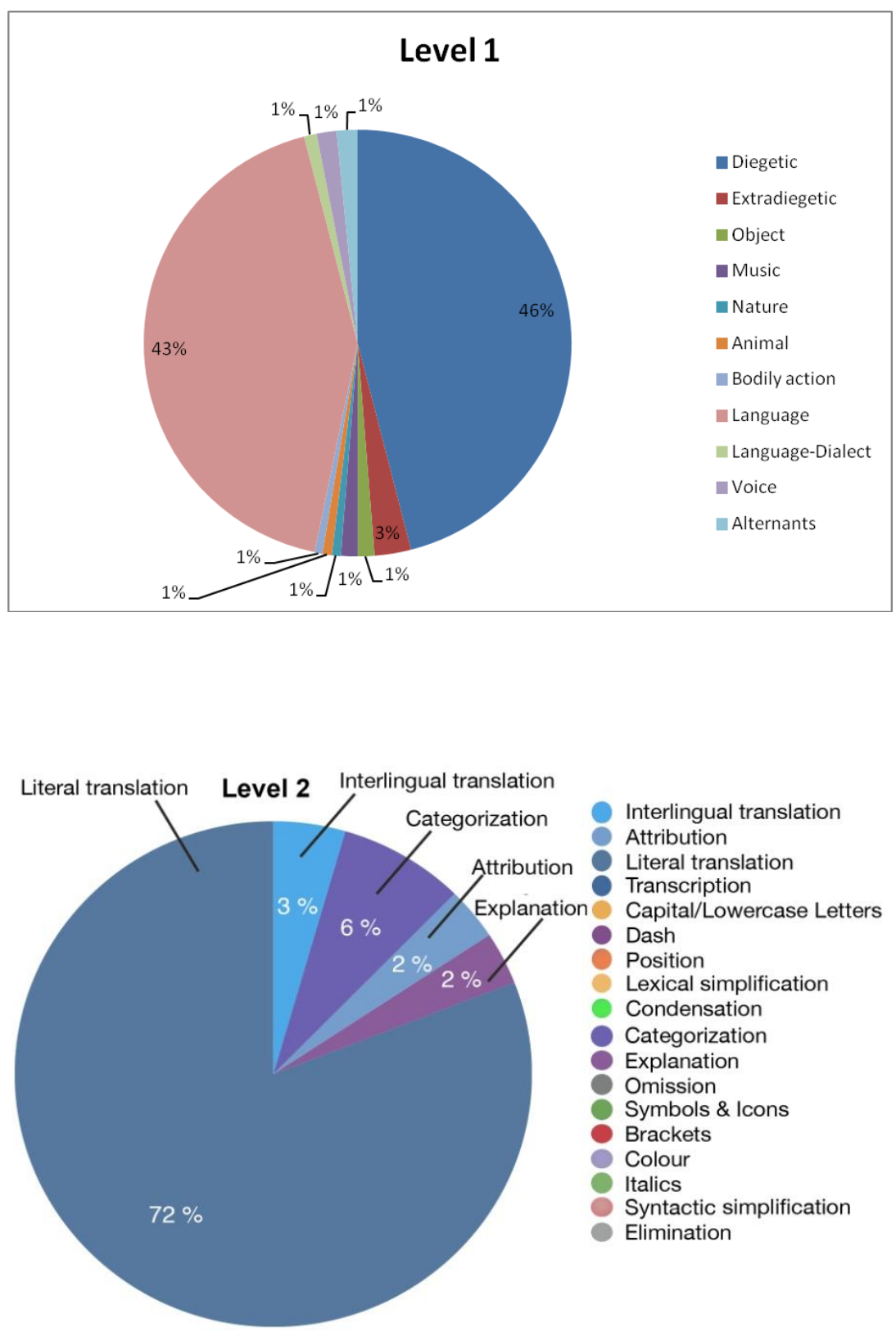

Figure 6: Percentages for tags belonging to Level 1

Figure 7: Percentages for tags belonging to Level 2

The pie chart for translation strategies in Figure 7 reflects the predominance of intralingual translation in the Literal translation tag, which has a frequency of $72 \%$. Together, the other strategies such as intersemiotic translation and interlingual translation had a frequency of use of only $28 \%$. Surprisingly, Lexical simplification, Syntactic simplification, Condensation and Elimination had a percentage of less than $1 \%$ each (which are not included in the chart). Evidently, these strategies are rarely used in SDHH. Literal translation is the most commonly used strategy. 


\subsection{Comparative analysis of four subtitling companies}

The TRACCE-SpS corpus is composed of four subcorpora corresponding to four companies or work groups: Cine para todos (Aristia Producciones), Navarra de cine, El Pais and Others. Table 3 lists the companies and shows the tendency of each subcorpus.

Table 3: Tag frequencies for each of the four subcorpora

\begin{tabular}{|c|c|c|c|c|c|}
\hline & \multirow[b]{2}{*}{ Tag } & \multicolumn{4}{|c|}{ Frequency } \\
\hline & & $\begin{array}{l}\text { Cine para } \\
\text { todos }\end{array}$ & $\begin{array}{l}\text { Navarra de } \\
\text { cine }\end{array}$ & ElPaís & Others \\
\hline \multirow[t]{2}{*}{ Film narratology } & Diegetic & 12359 & 19468 & 4539 & 1315 \\
\hline & Extradiegetic & 509 & 1475 & 56 & 48 \\
\hline \multirow{2}{*}{$\begin{array}{l}\text { Physical nature of sound: } \\
\text { artificial }\end{array}$} & Objet & 157 & 433 & 8 & 31 \\
\hline & Music & 469 & 382 & 18 & 14 \\
\hline \multirow{7}{*}{$\begin{array}{l}\text { Physical nature of sound: } \\
\text { natural }\end{array}$} & Nature & 8 & 49 & 0 & 0 \\
\hline & Animal & 22 & 61 & 0 & 0 \\
\hline & Bodily action & 32 & 146 & 0 & 11 \\
\hline & Language & 11454 & 18124 & 4359 & 1059 \\
\hline & Language-Dialect & 544 & 32 & 5 & 0 \\
\hline & Voice & 240 & 763 & 5 & 33 \\
\hline & Altermations & 459 & 589 & 0 & 52 \\
\hline Interlingual translation & Interlingual translation & 596 & 761 & 0 & 0 \\
\hline \multirow[t]{12}{*}{ Intersemiotic translation } & Omission & 4 & 33 & 117 & 0 \\
\hline & Transcription & 138 & 187 & 0 & 0 \\
\hline & Categorization & 1151 & 1212 & 3 & 48 \\
\hline & Attribution & 157 & 802 & 1 & 11 \\
\hline & Explanation & 212 & 674 & 3 & 25 \\
\hline & Symbols \& Icons & 92 & 3 & 0 & 0 \\
\hline & Capita//Lowercase Letters & 129 & 281 & 1 & 48 \\
\hline & Brackets & 0 & 9 & 0 & 0 \\
\hline & Dash & 0 & 1 & 3 & 0 \\
\hline & Colour & 0 & 0 & 1 & 0 \\
\hline & Position & 126 & 560 & 38 & 51 \\
\hline & Italics & 0 & 420 & 2 & 0 \\
\hline \multirow[t]{6}{*}{ Intralingual translation } & Literal translation & 10732 & 16403 & 4278 & 1116 \\
\hline & Lexical simplification & 5 & 45 & 1 & 0 \\
\hline & Syntactic simplification & 56 & 161 & 28 & 0 \\
\hline & Condensation & 94 & 111 & 48 & 0 \\
\hline & Elimination & 64 & 255 & 130 & 0 \\
\hline & Subtitles units & 13556 & 21918 & 4654 & 1299 \\
\hline
\end{tabular}

For example, even though all of the companies translate extra-diegetic sounds (e.g., voice off or the background music accompanying the narrative), Navarra de cine has the highest frequency of this category. This signifies that this subtitling company regards extradiegetic sound as important for the user in comparison to other companies. In contrast, the frequency for El País is much lower, which means that in their subtitled films, any sound that was not dialogue was ignored.

At the physical-artificial level, the Object tag refers to artificial sounds produced by human beings (vehicles, telephones, radios, doors, etc.). This tag is most often used by Others (A Contracorriente Films S.L.), despite the fact that this subcorpus consists of only one film. This is probably due to the fact that the film is a comedy with a lot of 
action. However, it also indicates the importance of this phenomenon. Other companies that frequently use this tag are Navarra de cine and Cine para todos.
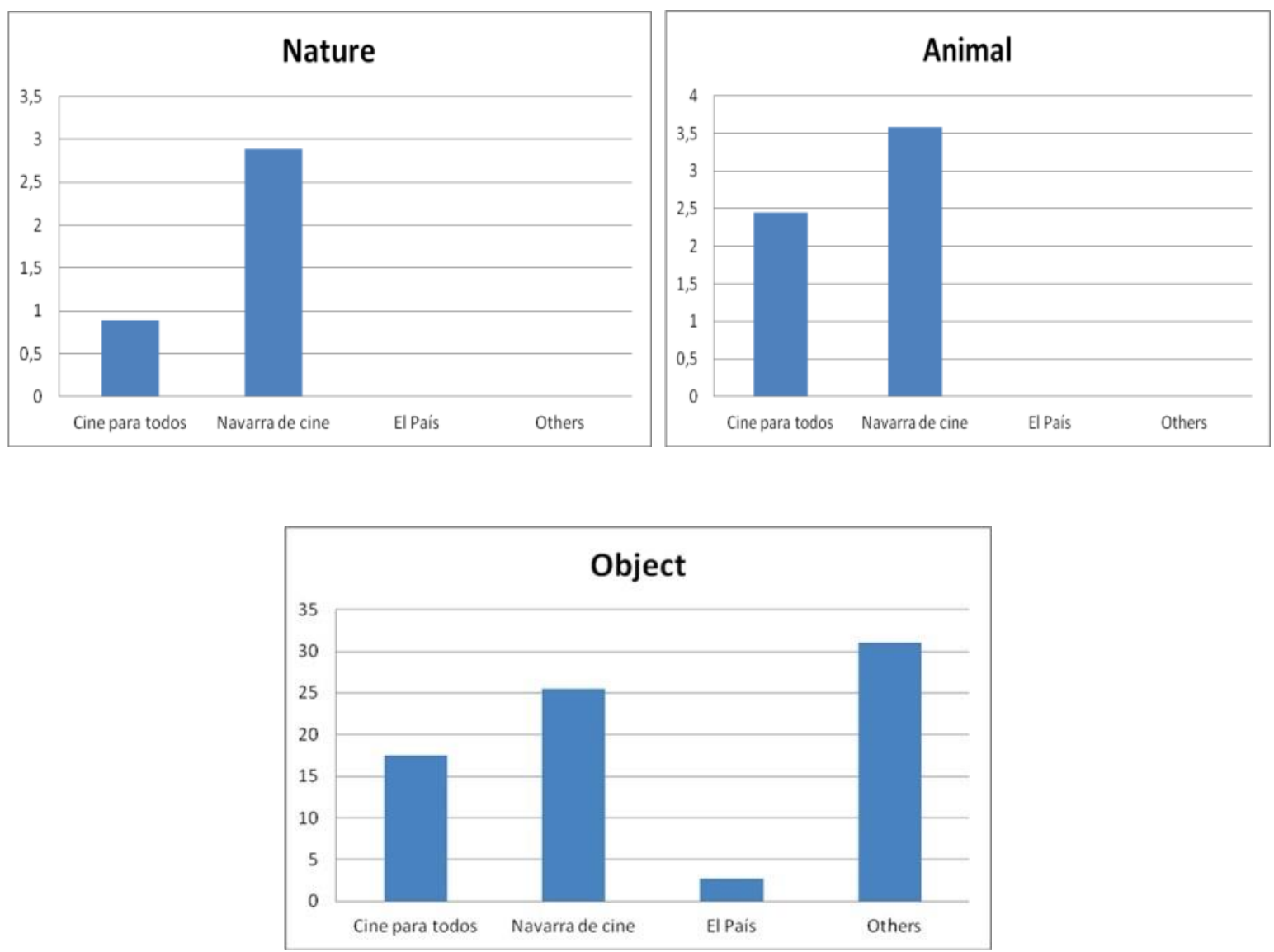

Figures 8, 9 and 10: Comparison of the subcorpora of Nature, Animal and Object tags

The tags for Animal and Nature entities are important because they help to immerse the DHH person in a more contextualized reality. As can be observed, the subcorpora of Others and El Pais reflect the fact that neither animals nor nature entities were selected. In contrast, the subtitles of Navarra de cine are extremely rich in meaning since they transmit practically all of the sounds produced in the world, followed at a distance by Cine para todos (see Figures 8 and 9).

The Level 2 data regarding the translation strategies most often used by each company reflect interesting tendencies, which in the future will have to be explored in greater depth. 

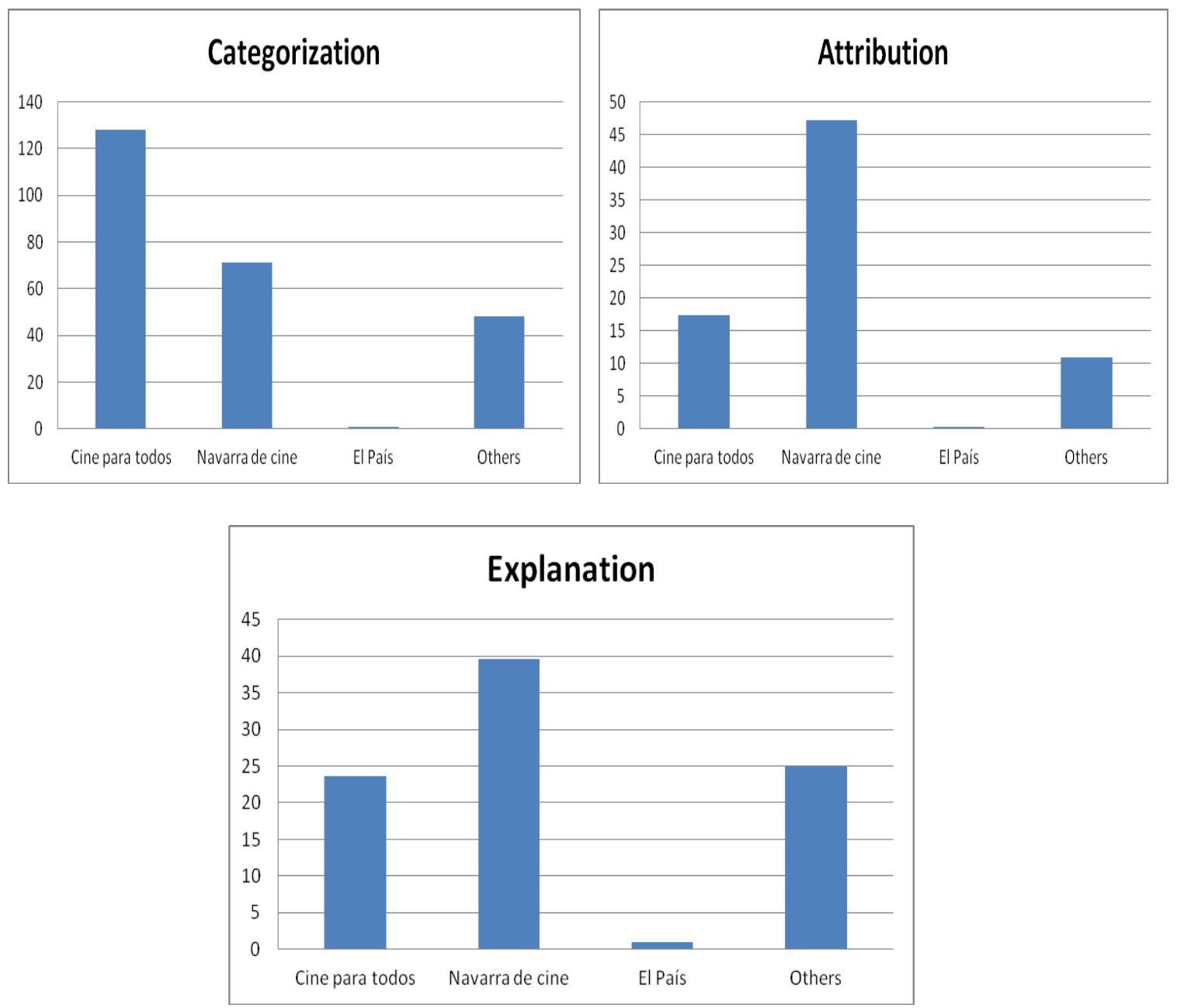

Figures 11, 12 and 13: Comparison of the subcorpora of the Categorization, Attribution and Explanation tags.

Graphs 11,12 and 13 show that Navarra de cine generally attributes qualities to the different types of sound and complements this information with explanations. In contrast, Cine para todos categorizes the sound only for the DHH person. Evidently, this selection and use of different strategies is a topic that would be worth studying in the future.

\subsection{Analysis according to film genre}

This section examines the use of each tag, depending on film genre (i.e., comedy, children's films, romantic comedy, documentary films, action/thriller). Since each genre is composed of different films, this analysis was carried out by calculating the average value of each of the six genres. This value was compared to the average value for the general corpus. In this way, reliable data were obtained for the six groups. This allowed us to ascertain whether the tendencies were similar for all of the genres or whether there were differences. Figures 14, 15 and 16 show the data for Nature, Bodily action and Animal. 

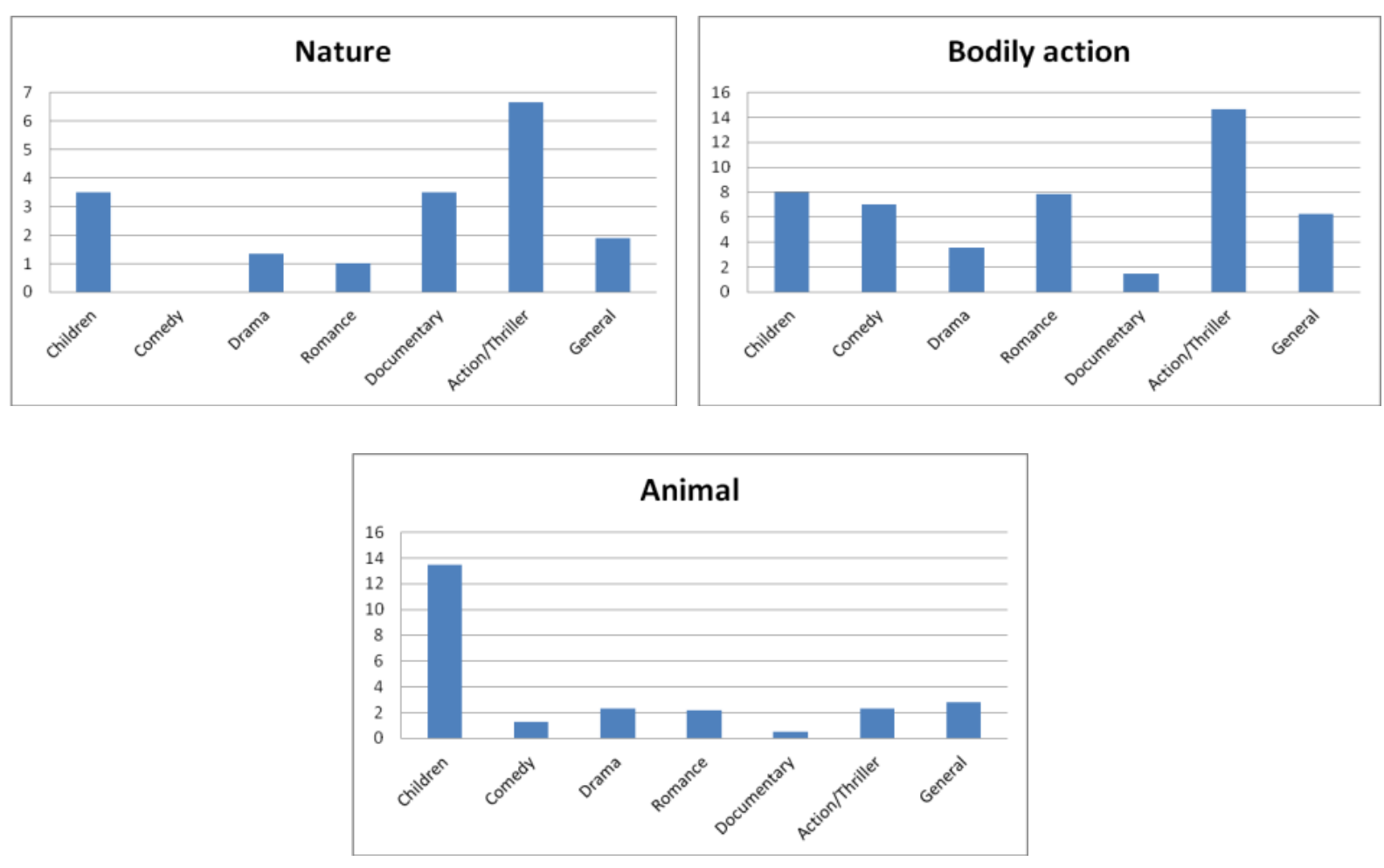

Figures 14, 15 and 16: Comparison of Nature, Bodily action and Animal tags, depending on film genre

The graphs in Figures 14, 15 and 16 show that the translation of sounds produced by Nature and Bodily action is much more frequent in the action/thriller genre. In contrast, in children's films, animal sounds predominate. Strikingly, the frequency of almost all tags is higher in this genre than in the others. In other words, there is a tendency to translate more sounds for children.

\subsection{Cross-matching tags of both levels: the translation process revisited}

One of the most interesting aspects of the process of translating sound into words is that translators seem to be intuitively aware that they must apply a kind of general translation strategy that involves simplifying the message transmitted and which includes the following:

- general simplification of the acoustic event by designating it with a generic noun (categorization);

- modification of the noun with an adjective designating one of its properties (categorization with some kind of attribution);

- $\quad$ modification of the whole with an explicative phrase (with an explanation).

Although this strategy may permit DHH people easier access to knowledge of the sounds in the ST, the resulting semantic and pragmatic variation becomes another obstacle that must be overcome. Since there are no clear guidelines, this type of translation is performed arbitrarily without recourse to a standard procedure or the use of the same or similar syntactic and lexical structures.

As will be seen, the cross-matching of Level 1 tags (audio mode) and Level 2 tags (translation strategies) provided data regarding how tagged acoustic elements were 
translated and the resulting linguistic structures. The objective was to relate the triad composed of sound type, translation strategy and linguistic expression in the subtitle (Jiménez Hurtado \& Martínez Martínez, 2017).

\section{Sound type}

\section{Translation} strategy

\section{Linguistic expression}

Figure 17: Three components of the translation process

These data made it possible to document definitively the course and direction of the translation process, since it provided information about the selected item of the ST, that is, the acoustic elements in the film, the translation strategy used to put them into words and the linguistic structure activated to create the ST.

In what follows, we show the results of cross-matching various Level 1 sound tags with Categorization, a Level 2 tag referring to one of the translation strategies. As can be observed in Table 4, there is evidence of considerable linguistic variation in the production of the ST. 
Table 4: Cross-matching of category tags with those for sound types

\begin{tabular}{|c|c|c|c|c|}
\hline \multicolumn{5}{|c|}{ STRATEGY CATEGORIZATION } \\
\hline Nature & Animal & Human & Object & Music \\
\hline (Viento) & (Ladridos) & (SE QUEJA) & (Móvil) & (Música de órgano) \\
\hline [Wind] & [Barking] & [Complaining] & [Mobilephone] & [Organ music] \\
\hline (Rumor de mar) & (Aullidos) & (Parloteo) $\times 2$ & (Portazo) & (Música en crescendo) \\
\hline [Murmur of the sea] & [Hooting] & [Chattering] & [Slamming door] & [Music getting louder] \\
\hline (Truenos) & (Maullido) & (EBRIO) & (Teléfono) & (Toque de corneta) \\
\hline [Thunder] & [Meowing] & [Drunk] & [Telephone] & [Bugle call] \\
\hline (Ulular del viento) & (Aleteo de insecto) & (GRITA) & (Golpe) & (Música) \\
\hline \multirow[t]{9}{*}{ [Wailing of the wind] } & [Buzzing of insects] & [Shouting] & [Impact] & [Music] \\
\hline & (Gaviota) & (Grito) & (Tres campanadas) & (Órgano) \\
\hline & [Seagull] & [Shout] & [Three chimes] & [Organ] \\
\hline & (Aleteo de palomas) & (LLORA) & (Frenazo) & \\
\hline & [Flapping of pigeons] & [Cry] & [Braking] & \\
\hline & (Graznido de gaviotas) & (Risa) & (Ascensor) & \\
\hline & [Squawking of seagulls] & [laugh] & [Lift] & \\
\hline & (CON SERIEDAD) & (Bocina) & & \\
\hline & [Serious] & [Horn] & & \\
\hline
\end{tabular}

A cross-matching of the tag Categorization with the Level 1 tag for Nature shows that their translation focuses on the sound source (wind, thunder) as well as the type of sound emitted (murmur of the sea, wailing of the wind). The data therefore indicate that when a nature sound is translated into words, its category is often explicitly mentioned.

SOUND SOURCE: wind, thunder

SOUND PRODUCED + SOUND SOURCE: wailing of the wind, murmur of the sea

Something similar occurs with the tag Animal. On the one hand, there is reference to the sound source that is either activated by the referent (dog, seagull) or by the generic term (animal). Moreover, the animal sound itself may also be lexicalized (barking, meowing, squawking). 
SOUND SOURCE: generic term (animal) or more specific term (seagull)

SOUND SOURCE + ACTION PRODUCED BY THE SOURCE: Flapping of pigeons

SOUND PRODUCED: Barking

SOUND PRODUCED + SOUND SOURCE: Squawking of seagulls, barking of dogs

In the category of artificial sound, Object also has distinctive features. Although, generally speaking, the sound source is identified, there are four additional types of linguistic phenomenon in the ST:

- $\quad$ Reference to the type of sound produced by the object (ringing, slamming), especially when the sounds made by the object are countable (three chimes).

- $\quad$ Reference to a sound source (lift) that has no prototypical sound associated with it.

- Reference to action verbs (braking) that categorize an event but which are not related to a specific means of achieving the action involved.

Music is characterized by the generic term music in combination with the sound source (organ music) or only the sound source (organ). Another possibility is for the sound produced by the object to appear with the object (bugle call).

The category Human refers to non-articulated sounds made by human beings. Unlike the other categories, human beings (as a sound source) are not intrinsically determined by the sound that they produce. Perhaps for this reason, the terms for human sound also codify suprasegmental elements related to emotional content.

- Categorization of the way in which the sound or message is emitted (shout).

- Categorization of the action performed and what the sound involves when it is related to a certain emotion (cry, laugh). It is true of those sounds that can be inferred from the image. This indicates a redundancy that is usually regarded as necessary.

- $\quad$ Categorization of a state of mind (serious) or physical state (tired) as long as it is expressed by means of a suprasegmental sound that modifies the voice (drunk).

- Categorization of speech acts (complaining), which also involve a variation in tone or voice.

The results of our study show the wide range of acoustic elements selected by subtitlers when they translate films for people who are DHH. Furthermore, this diversity exists between individuals who subtitle the same film. Such differences can also be seen in the comparison of different companies as well as in the case of different film genres. This lack of systematicity is even more evident when data related to different translation strategies are analysed. It is surprising that the same acoustic phenomenon not only activates different translation strategies but is also lexicalized by linguistic structures that are far from being homogeneous.

\section{Conclusions}

The results of this study provide valuable insights into the translation of sounds into words when the sound is part of a complex multimodal text, such as a film that is subtitled for DHH viewers. This article shows that the corpus-based analysis of tagged multimodal texts is an effective tool for identifying the cognitive characteristics of intersemiotic translation in all its complexity.

The creation of a set of tags as well as a tagged corpus must have a clear objective. In the case of the TRACCE-SpS corpus, the goal was to obtain data regarding the epistemology of the process of translating sounds into words. To tag the STs, we 
elaborated a system of tags based on acoustic theory and on studies of film sound. These are known as audio-mode or Level 1 tags. However, it was necessary to create a second system of tags for the cognitive strategies used in the translation process. Although some of these tags are based on premises from Translation Studies, it was necessary to complement them with others. Throughout the complex tagging process and thanks to the interrater evaluation and agreement, a method of analysis frequently applied in studies of tagged corpora, we were able to discover innovative strategies that required in-depth study, such as Categorization, Attribution and Explanation.

The data collected have allowed us to analyse the different types of sound that subtitlers regard as relevant in the multimodal meaning-making process. Furthermore, this research includes evidence of the statistically relevant tendency of these data, based on the frequency of use of each tag in the corpus in general as well as in the different subcorpora with regard to subtitling companies or film genres.

Finally, this study provides empirical data that confirm previous intuitions and suppositions regarding this modality of subtitling. More specifically, it seems that there is still no coherent translation of sounds in SDHH. In their work, professional subtitlers tend to simplify the text so as to help DHH people quickly access sound-related information. This allows them to be able to interpret it in relation to the images. However, this access through simplification is often nullified by the wide range of linguistic variations that can appear in the text of the subtitles.

Despite the fact that the method showed the usefulness of corpus analysis as applied to multimodal translation, it is necessary to find a way of annotating the corpus that is more cost-effective with respect to time and human resources. Only with a coherent and more suitably developed set of tags will it be possible to analyse the reasons for the proven variability and inconsistency in the translation process or to obtain new insights into the quality of the results.

\section{Acknowledgements}

This research was carried out within the framework of the project OPERA [Leisure and culture accessibility. Online portal for the dissemination and evaluation of accessible audiovisual resources (FFI2015-65934-R)], funded by the Spanish Ministry of Economy, Industry and Competitiveness.

\section{References}

Abuczki, A., \& Ghazaleh, E. B. (2013). An overview of multimodal corpora, annotation tools, and schemes. Argumentum, 9, 86-98.

AENOR, UNE 153010 (2012). Subtitulado para personas sordas y personas con discapacidad auditiva. Madrid: Asociación Española de Normalización y Certificación.

Allwood, J. (2008). Multimodal corpora. In A. Lüdeling \& M. Kytö. (Eds.), Corpus linguistics: An international handbook (pp. 207-225). Berlin: Mouton de Gruyter.

Álvarez de Morales Mercado, C. (2015). El Subtitulado para personas sordas como discurso narratológico. Sendebar, 26, 57-81.

Amor. (2012). [film] Directed by M. Haneke. France: Michael Haneke.

Bateman, J. A., Delin, J., \& Henschel, R. (2004). Multimodality and empiricism: Preparing for a corpusbased approach to the study of multimodal meaning-making. In E. Ventola, C. Charles, \& M. Kaltenbacher (Eds.), Perspectives on multimodality (pp. 65-87). Amsterdam: John Benjamins.

Baldry, A., \& Thibault, P. J. (2006). Multimodal transcription and text analysis: A multimedia toolkit and course book. London: Equinox.

Baños Piñero, R., \& Díaz Cintas, J. (2015). Audiovisual translation in a global context: Mapping an everchanging landscape. Basingstoke: Palgrave Macmillan. 
Bordwell, D., \& Thompson, K. (2010). El arte cinematográfico: Una introducción. Barcelona: Paidós.

Cabo Villarpriego, M. B. (2008). Estudio de estrategias de reducción en el subtitulado en español para sordos de Scoop, (Woody Allen, 2006) (Unpublished master's thesis). University of Vigo, Spain.

Cambra i Vergés, C. (2006). Los subtítulos en televisión: ¿Facilitan a los adolescentes sordos la comprensión de los programas? FIAPAS (Federación Española de Asociaciones de Padres y Amigos de los Sordos), 110, 28-31.

Cambra, C., Silvestre N. \& Leal A. (2015). Los subtitulos actuales no garantizan la comprensión de los mensajes televisivos al alumnado con sordera. Retrieved from http://www.agenciasinc.es/Noticias/Los-subtitulos-actuales-no-garantizan-la-comprension-de-losmensajes-televisivos-al-alumnado-con-sordera.

Chica Núñez, A. J. (2016). La traducción de la imagen dinámica en contextos multimodales. Granada: Tragacanto.

Chion, M. (2008). La audiovisión: Introducción a un análisis conjunto de la imagen y el sonido. Barcelona: Paidós.

Cuadrado Méndez, F. J. (2013). Los procesos de auricularización en el cine. Revista Comunicación, 11(1), 24-39.

De Moraes Abrahão, V. (2014). A corpus based analysis of verbs in subtitles for deaf and hard-of-hearing and audiodescriptions (Unpublished master's thesis). University Complutense de Madrid, Spain.

Díaz Cintas, J. (2003). Teoría y práctica de la subtitulación (inglés-español). Barcelona: Ariel.

Díaz Cintas, J. (2005). Nuevos retos y desarrollos en el mundo de la subtitulación. Puentes, 6, 13-20.

Díaz Cintas, J., \& Remael, A. (2007). Audiovisual translation: Subtitling. Manchester: St. Jerome.

Díaz Cintas, J. (2010). Subtitling. In Y. Gambier \& L. van Doorslaer (Eds.), Handbook of translation studies. Volume 1 (pp. 344-349). Amsterdam: John Benjamins.

Díaz Cintas, J., \& Neves J. (2015). Audiovisual translation: Taking stock. Cambridge: Cambridge Scholars.

Elleström, L. (2010). The modalities of media: A model for understanding intermedial relations. In L. Elleström (Ed.), Media borders, multimodality and intermediality (pp. 11-48). Basingstoke: Palgrave Macmillan.

Enríquez, F., Troyano, J. A., Cruz, F., \& Ortega F. J. (2006). Ampliación automática de corpus mediante la colaboración de varios etiquetadores. Procesamiento del Lenguaje Natural, 37, 11-18.

Evans, V., \& Green M. (2006). Cognitive linguistics: An introduction. Edinburgh: Edinburgh University Press.

Feitosa, M. P. (2009). Legendagem pirata e legendagem comercial: Um estudo comparado (Unpublished doctoral dissertation). University Federal de Minas, Belo Horizonte, Brazil.

Flückiger, B. (2001). Sound design: Die virtuelle Klangwelt des Films. Marburg: Schüren.

Gorbman, C. (1987). Unheard melodies. London: BFI.

Gruber, T. (1995). Toward principles for the design of ontologies used for knowledge sharing. International Journal of Human-Computer Studies, 43(5-6), 907-928.

Gruber, T. (2001). What is an ontology? Retrieved from http://www.ksl.Stanford.edu/ kst/what-isanontology.html.

Heiss, C., \& Soffritti, M. (2008). Forlixt 1 - The Forlì Corpus of Screen Translation: Exploring microstructures. In D. Chiaro, C. Heiss, \& C. Bucaria (Eds.), Between text and image: Updating research in screen translation (pp. 51-62). Amsterdam: John Benjamins.

Ivarsson, J., \& Carroll M. (1998). Subtitling. Simrisham: TransEdit.

Jakobson, R. (1959). On linguistic aspects of translation. In R. A. Brower (Ed.), On translation (pp. 232239). Cambridge, MA: Harvard University Press.

Jewitt, C. (2009). An introduction to multimodality. In C. Jewitt (Ed.), The Routledge handbook of multimodal analysis (pp. 14-27). New York, NY: Routledge.

Jiménez Hurtado, C. (2007). Traducción y accesibilidad: Subtitulación para sordos y audiodescripción para ciegos: nuevas modalidades de traducción audivisual. Frankfurt: Peter Lang.

Jiménez Hurtado, C. (2010). Fundamentos teóricos del análisis de la AD. In C. Jiménez Hurtado, A. Rodríguez Domínguez, \& C. Seibel (Eds.), Un corpus de cine: Teoría y práctica de la audiodescripción (pp. 13-56). Granada: Ediciones Tragacanto.

Jiménez Hurtado, C., Seibel, C., \& Soler Gallego, S. (2012). Museos para todos: La traducción e interpretación para entornos multimodales como herramienta de accesibilidad universal. In R. 
Agost, P. Orero, \& E. di Giovanni (Eds.), Multidisciplinarity in audiovisual translation. MonTI, 4, 349-383.

Jiménez Hurtado, C., \& Soler Gallego, S. (2015). Museum accessibility through translation: A corpus study of pictorial audio description. In J. Diaz Cintas, J. Neves, \& D. Sánchez (Eds.), Audiovisual translation: taking stock (pp. 277-296). Cambridge: Cambridge University Press.

Jiménez Hurtado, C., \& Martínez Martínez, S. (2017). ¿Qué se oye?: El proceso traductor del subtitulado para personas sordas desde un estudio de corpus. In C. Gaona Pisonero, C. (Ed.), Temáticas emergentes en innovación universitaria (pp. 243-253). Colección: Ediciones Universitarias. Madrid: Editorial Tecnos.

Kalantzi, D. (2008). Subtitling for the deaf and hard of hearing: A corpus-based methodology for the analysis of subtitles with a focus on segmentation and deletion. (Unpublished doctoral dissertation). University of Manchester, United Kingdom.

Kaindl, K. (2013). Multimodality and translation. In C. Millán \& F. Bartrina (Eds.), The Routledge handbook of translation studies (pp. 257-268). New York, NY: Routledge.

Karamitroglou, F. (1998). A proposed set of subtitling standards in Europe. Translation Journal, 2(2), 115.

Kellner, R. (2011). Auditive Filmanalyse: Die Notwendigkeit bewusster Wahrnehmung von Filmton am Beispiel von David Lynchs "Mullholland Drive". Munich: GRIN.

Ketola, A. (2016). Translating picturebooks: Re-examining interlingual and intersemiotic translation. Proceedings of DRS 2016, Design Research Society 50th Anniversary Conference. Brighton, UK, 27-30 June 2016.

Konstantinidou, A. (2012). La física del sonido. In J. Gustems Carnicer (Ed.), Música y sonido en los audiovisuales (pp. 33-48). Barcelona: Edicions Universitat Barcelona.

Laviosa, S. (2015). Corpora and holistic cultural translation. In M. T. Sánchez Nieto (Ed.), Corpus based translation and interpreting studies: From description to application/Estudios Traductológicos basados en corpus: de la descripción a la aplicación (pp. 31-51). Berlin: Frank \& Timme.

Llinares, F. (2012). El sonido como recurso expresivo en los audiovisuales: La física del sonido. In J. Gustems Carnicer (Ed.), Música y sonido en los audiovisuales (pp. 135-146). Barcelona: Edicions Universitat Barcelona.

Lorenzo García, L., \& Pereira Rodríguez, A. (2011). Deaf children and their access to audiovisual texts: School failure and the helplessness of the subtitler. In E. di Giovanni (Ed.), Diálogos intertextuales 5: Between text and receiver: Translation and accessibility. Entre texto y receptor: Traducción y accesibilidad (pp. 185-201). Frankfurt: Peter Lang.

Martí Ferriol, J. L. (2010). Cine independiente y traducción. Valencia: Tirant lo Blanc.

Martí Ferriol, J. L. (2013). El método de traducción: Doblaje y subtitulación frente a frente. Universitat Jaume I, Castellón de la Plana: Trama.

Martínez Martínez, S. (2015). El Subtitulado para sordos: Estudio de corpus sobre tipología de estrategias de traducción (Unpublished doctoral dissertation). University of Granada, Spain.

Mattsson, J. (2009). The subtitling of discourse particles: A corpus-based study of well, you know, I mean, and like, and their Swedish translations in ten American films (Doctoral dissertation). University of Gotemburg, Germany.

Munday, J. (2012). Introducing translation studies: Theories and applications. London: Routledge.

Muñoz Martín, R. (2017). Looking toward the future of cognitive translation studies. In J. W. Schwieter \& A. Ferreira (Eds.), Handbook of translation and cognition (pp. 555-572). Malden, MA: WileyBlackwell.

Nancy, I., \& Pustejovsky, J. (2017). (Eds.). Handbook of linguistic annotation. Dordrecht: Springer.

Neves, J. (2005). Audiovisual translation: Subtitling for the deaf and hard-of-hearing (Doctoral dissertation). University of Surrey-Roehampton, London, UK.

Neves, J., \& Lorenzo García, L. (2007). La subtitulación para s/Sordos, panorama global y prenormativo en el marco ibérico. TRANS, 2, 95-113.

Pedersen, J. (2011). Subtitling norms for television. Amsterdam: John Benjamins.

Peña y Lillo, M. (2012). La importancia del acuerdo entre codificadores para el análisis del contenido. Comunicación y Medios, 25, 47-56. 
Pessoa do Nascimiento, A. K. (2017). Translating sounds into words in subtitles for the deaf and hard of hearing: A corpus based approach. Trabalhos em Linguística Aplicada, 56(2), 561-587.

Poyatos F. (1994, I, II.). La comunicación no verbal. Madrid: Istmo.

Ranzato, I., \& Zanotti, S. (2018). Linguistic and cultural representation in audiovisual Translation. New York, NY: Routledge.

Risku, H. (2014). Translation process research: From mental to socio-cognitive processes. In R. Muñoz Martín (Ed.), Minding translation, Special Issue MonTI, 331-384

Rumsey F., \& McCormick, T. (2014). Sonido y grabación. Madrid: Instituto Oficial de Radio y Televisión.

Salway, A. (2007). A corpus-based analysis of AD. In J. Díaz-Cintas, P. Orero, \& A. Remael (Eds.), Media for All (pp. 151-174). Amsterdam: Rodopi.

Schafer, R. M. (2003). El paisaje sonoro y la afinación del mundo. Barcelona: Intermedio.

Schwieter, J. W., \& Ferreira, A. (2017). (Eds.). Handbook of translation and cognition. Malden, MA: Wiley-Blackwell.

Sotelo Dios, P., \& Gómez Guinovart, X. (2012). A multimedia parallel corpus of English-Galician film subtitling. In A. Simões, R. Queirós, \& D. da Cruz (Eds.). Informatics, 21, 255-266.

Taylor, C. (2004). The language of film: Corpora and statistics in the search for authenticity. Notting Hill (1998) - A case study. Miscelánea, 30, 71-86.

Tiedemann, J. (2007). Building a multilingual parallel subtitle corpus. In P. Dirix, I. Schuurman, V. Vandeghinste, \& F. Van Eynde (Eds.), Proceedings of the 17th meeting of computational linguistics in the Netherlands (pp. 147-162). Utrecht: Utrecht University.

Tirkkonen-Condit, S., \& Mäkisalo, J. (2007). Cohesion in subtitles: A corpus-based study. Across Languages and Cultures: A Multidisciplinary Journal for Translation and Interpreting Studies, 8(2), 221-230.

Valentini, C. (2006). A multimedia database for the training of audiovisual translators, The Journal of Specialised Translation, 6, 68-84.

Valentini, C. (2008). Forlixt 1: The Forlì Corpus of Screen Translation: Exploring macrostructures. In D. Chiaro, C. Heiss, \& C. Bucaria (Eds.), Between text and image: Updating research in screen translation (pp. 37-50). Amsterdam: John Benjamins.

Zárate, S. (2014). Subtitling for deaf children: Granting accessibility to audiovisual programmes in an educational way (Unpublished doctoral dissertation). University College London, UK. 
1 According to Carol Padden and Tom Humphries, in Deaf in America: Voices from a Culture (1988), we use the lowercase deaf when referring to the audiological condition of not hearing and the uppercase Deaf when referring to a particular group of deaf people who share a Sign Language and a culture (https://www.nad.org/).

2 The films of this corpus are: Bienvenidos al norte (Boon, 2006), Cerezos en flor (Dörrie, 2008), Cuatro minutos (Kraus, 2006), Dos dias en París (Delpy, 2007), Pan y rosas (Loach, 2000) Saraband (Bergman, 2003), Habitación en Roma (Medem, 2010), Contra la pared (Akin, 2004), El árbol (Bertucelli, 2010), The good heart (Kári, 2009), Amor (Hanecke, 2012), Balada triste de trompeta (de la Iglesia, 2010), Ágora (Amenábar, 2009), Bon Appéttit (Pinillos, 2010), Combustión (Calparsoro, 2013), El cuerpo (Paulo, 2012), El planeta de los caracoles (Seung-jun, 2011), En un mundo mejor (Bier, 2010), Hair India (Brunetti \& Leopardi, 2008), La dama de hierro (Lloyd, 2011), Las nieves del Kilimanjaro (Guédiguian, 2011), Los abrazos rotos (Almodóvar, 2009), Los amantes pasajeros (Almodóvar, 2013), Malacara y el bastón de roble (Tinoco \& Jiménez, 2008), Mar adentro (Amenábar, 2004), María y yo (Fernández, 2010), No controles (Calleja, 2010), No habrá paz para los malvados (Urbizu, 2011), Scoop (Allen, 2006), Tengo ganas de ti (González, 2012), La piel que habito (Almodóvar, 2011) Las aventuras de Tadeo Jones (Gato, 2012), Lope (Waddington, 2010), Match Point (Allen, 2005), Torrente 4: Lethal Crisis (Crisis Total) (Segura, 2011), Primos (Sánchez, 2011), Chantaje (Barker, 2007), Grupo 7 (Rodríguez, 2012), Lo imposible (Bayona, 2012), Pagafantas (Cobeaga, 2009), Slumdog Millonaire (Boyle \& Tandan, 2008), Soul Kitchen (Akin, 2009), Transsiberian (Anderson, 2008), Crash (Haggis, 2004), El laberinto del fauno (Del Toro, 2006), El discurso del rey (Hooper, 2010), Intocable (Nakache \& Toledano, 2011), Laberinto de pasiones (Almodóvar, 1982), La mala educación (Almodóvar, 2004), Hable con ella (Almodóvar, 2002), La pasión de China Blue (Russell, 1984) and Elsa \& Fred (Carnevale, 2005). 